\title{
Effectiveness of Contextual Science Practicum Module to Improve Science Process Skills and Environmental Caring Character
}

\author{
Ni Luh Putu Rusmana Dewi*, I Wayan Suastra, and Ni Made Pujani \\ Science Education, Post-Graduate Program, Universitas Pendidikan Ganesha, Singaraja, Bali, \\ Indonesia
}

\begin{abstract}
This study aims to examine the effectiveness of contextual science practicum module to improve science process skills and environmental caring character. The type of this research is research and development refers to the Thiagarajan development model which carried out until development. Before effectiveness test, the validity and practicality of the module were tested. The effectiveness data of practicum module was obtained through a limited field trial conducted with 30 sample of student. The effectiveness test of the module were analyzed using pre experimental method with One Shot Case Study design. The results are: (1) the validity of the practicum module is 3.40 belong to valid category; (2) the practicality of practicum module is 3,50 belong to very good category; and (3) the effectiveness of the practicum module viewed from the skills of the science process is 85,86 belong to good category and the score of students environmental cares at moral knowing is 3,53 belong to entrust category and the score at moral behavior is 3,22 belong to developing category, so the module can be declared effective. The implication of this research is the teacher should understand the component of contextual approach and provide the supporting equipment of practicum activity. Keyword: science practicum module, contextual, science process skills, environmental caring character
\end{abstract}

\section{Introduction}

The quality of science learning, especially the science process skills and the environmental cares Indonesian students are still low. This fact is supported by the PISA 2015 value index, indicating that the scores of Indonesian students' science is only 403 are still below the average score is 493 [1]. This problem caused by the practicum system is not applied as a source of student learning, whereas lot of IPA topics, Particularly pollution topic will find a lot of application in the daily life of students in the environment. Currently, the assessment used to assess student learning outcomes $100 \%$ from cognitive aspect by using quiz, test in ending of topics, final test, and home work without assessing student performance so the students' science skills become less developed [2].

*Corresponding author: rusmanadewi@rocketmail.com 
Meanwhile, the emergence of crisis in character of the nation, especially the character of the environment caring caused by the current education failed to develop the education value in school [3]. There are lot of learning in schools that only transfer knowledge to student without inserting noble values or character education so the impact are moral decline and behavior not responsible.

The solution of this problems is developing the contextual science module and doing test of effectiveness. The characteristics of the new developed practicum modules be adapted with student life (contextual) and modified by a simple set of practicum and following the contextual learning component. With this concept, the practicum will be more interesting and fun for students because it brings the science problem into everyday life[3].

Contextual learning is an alternative to a teacher to teach by connecting the lessons with the real-world situations of the students or the students' daily experiences [4]. This is as a stock of students to solve problems in their life as a member of society[5]. CTL approach is very relevant if raised and used in science practicum activities because it considers the contextual aspects and components of the CTL approach, such as: contructivisme, modelling, learning community, inquiry, questioning, refleksi, dan autentic assesment.

Science process skills is process approaches used by the teachers in discussing content that refers to the process of science [6]. Scientific process skills are also defined as skills possessed by scientists [7]. Scientific process skills are needed as a basis for students to solve a problem. Therefore, curriculum in the schools for the science topics are advised to apply science process skills to teach science. Scientific process skills can be trained through the laboratory activities (practicum) contextually [8]. When practicum activities were done with contextual approach, the interaction of knowledge of the students with learning environment will happened. Therefore, the student interest of IPA topics will be increasing so that students' science process skills will also increase. The indicators of science process skills studied include; 1) formulate hypotheses, 2) doing experiments, 3) observations, 4) implementing concepts, and 5) communicate.

The environment caring character is an attitude and action that always strives to prevent the destruction of the surrounding natural environment and always try to repair the existing natural damage. The achievement indicators of environmental caring values are: 1) hard work to protect nature, 2) appreciate health and hygiene, 3) wise in using natural resources, and 4) responsibility to the environment [9]. The process of internalizing characters through three important stages [10]: First, students have a knowledge of the good (moral knowing). Secondly, from the knowledge of goodness, the commitment of the students to the good (moral feeling) was arises. Third, after students have a commitment to goodness, they end up actually doing good (moral behavior). The process of applying the characters in the daily life of learners can be done through contextual learning, because learning is done naturally, so that student can practice the characters has been learned [11].

The contextual science practicum module in this study is practical module adapted with the daily life of the students (contextual) with a simple set of practicum and follows the components of contextual learning. Given the essence of practicum in science learning, the effort to make the practicum as a simple and easy activity is very important. One way for practicum to be done easily is to relate it to the real situation in the student environment (contextual). In this way, the practicum will be more interesting and fun for students because it brings the science problem into everyday life[12]. 


\section{Method}

This research is aimed to a model testing through the development of a product of teaching moduls of science SMP. The method of this research is research and development. The developed product is contextual science practicum module for junior high school second semester class VII on environmental pollution topic. The development model for teaching modul used in this study is a model of development suggested by Thiagarajan et al. (1974) is a 4-D model. This model consists of 4 stages of development, such as define, design, develop, and disseminate. In this study only done until the stage of develop because of limitations of researchers. The design of the effectiveness test of the module is done by using pre experimental method with One Shot Case Study design.

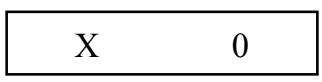

Figure 1. One Shot Case Study Research Design [13].

The subjects in this study were the people involved to obtain information about the practicum module consisting of the experts, the practitioners and the students. The experts are from the lectures and focus for obtaining data on the validity of the practicum modules. Practitioners come from the science teachers of junior high school and focus in obtaining data about the practicality. The students focus in obtaining data about the practicality and effectiveness of teaching modul. Students as subject are taken as one class that is class VII SMP.

The practicum modul that were tested for effectiveness is the contextual science practicum module for Junior High School developed on environmental pollution topic. The practicum activities developed include: 1) polluted water features, 2) water purification methods, 3) air pollution in the surrounding environment, 4) contamination of tobacco smoke, 5) contamination of soil in surrounding environment, and 6) detergent effect on plant growth. The data collection technique used in this research is by using several instruments such as: (1) teaching material validation sheet, (2) observation sheet of learning implementation, (3) teacher response questionnaire, (4) student response questionnaire, (5) observation sheet Science process skills, (6) observation sheets of environmental cares, and (7) environmental character questionnaires. This modul will have effectiveness in improving students 'science process skill when it reaches a minimum score of 80 with good category and will have the effectiveness of improving students' environmental cares character when minimum average score 2.5 with category start to develop. To test the effectiveness of the module is done by testing the hypothesis through $\mathrm{t}$ test one party with the help of software SPSS 16 for windows.

\section{Result and Discussion}

The validity of module is 3,40 with valid category, practicality result of the module are 3,50 in implementation module, 3,54 in teacher response, and 3,53 in student response belong to very practical category. Furthermore, the effectiveness of the module is derived from the value of the science process skills and students environmental caring character. 
Table 1. Result of Student Science Process Skills Observation

\begin{tabular}{|c|l|c|c|}
\hline No. & \multicolumn{1}{|c|}{ Indicator } & Value & Category \\
\hline 1 & Formulate Hypotheses & 90,13 & Very good \\
\hline 2 & Doing Experiments & 84,86 & Good \\
\hline 3 & Observation & 85,27 & Good \\
\hline 4 & Implementing Concepts & 85,97 & Good \\
\hline 5 & Communicate & 83,05 & Good \\
\hline \multicolumn{2}{|c|}{$\overline{\boldsymbol{x}}$} & $\mathbf{8 5 , 8 6}$ & Good \\
\hline
\end{tabular}

Table 2. Result of Student Environmental Caring Character Observation

\begin{tabular}{|c|c|c|c|}
\hline No. & Indicator & Average Score & Category \\
\hline 1 & Hard work to protect nature & 3,51 & Entrust \\
\hline 2 & Appreciate health and hygiene & 2,99 & Developing \\
\hline 3 & Wise in using Natural Resources & 3,29 & Developing \\
\hline 4 & Responsibility to the environment & 3,09 & Developing \\
\hline \multicolumn{2}{|c|}{$\overline{\bar{x}}$} & 3,22 & Developing \\
\hline
\end{tabular}

Table 3. Result of Student Environmental Caring Character Questionnaire

\begin{tabular}{|c|l|c|c|}
\hline No. & \multicolumn{1}{|c|}{ Indicator } & Average Score & Category \\
\hline 1 & Hard work to protect nature & 3,60 & Entrust \\
\hline 2 & Appreciate health and hygiene & 3,49 & Developing \\
\hline 3 & Wise in using Natural Resources & 3,57 & Entrust \\
\hline 4 & Responsibility to the environment & 3,46 & Developing \\
\hline \multicolumn{2}{r|}{$\overline{\boldsymbol{x}}$} & $\mathbf{3 , 5 3}$ & Entrust \\
\hline
\end{tabular}

The result of science process skill of student obtained the average value of 85.86, that's mean that students' science process skills are in good category. This result is reinforced by hypothesis testing through left side $t$ test which got result that $t=4,007$ bigger than $t$ table, that's mean, the average score of student science process skill is in good category. So it can be concluded that practicum activities using the contextual module is effective to improve students' science process skills. The results of this study are in line with the results of research conducted by Ting \& Siew [6] which shows that contextual learning can improve the skills of the science process. This is because contextual learning can help students to build more complex cognitive structures with real activities. Through the interaction between environments, students will be able to apply the skills of the science process to solve better everyday problems. In line with Ting \& Siew, Crawford [15] reveals that realistic, authentic, challenging, and contextualistic exercises or tasks were more effective for students and can build new knowledge or strengthen existing knowledge.

The success of the contextual practicum module in improving the science process skills is also due to the relationship between each component of contextual learning with science process skill indicators, such as: The 'contructivisme' component facilitates the process skills for formulating the hypotheses and applying concepts, the 'modeling' component facilitates the skills of the experimental process, the 'questioning' component facilitates the process of formulating the hypotheses, the 'inquiry' component facilitates experimental process skills and makes observations, the components of the 'learning societies' facilitating experimental process skills and applying concepts, the' reflection 'component facilitates the 
communication process skills, the' authentic assessment 'component facilitates the communication process skill.

The average score of environmental caring characters obtained based on the results of character observations of 3.22 with the developing category, while based on the questionnaire obtained an average score of 3.53 with the entrust category. This difference indicates that the process of internalization of the environmentally caring character in the understanding phase (moral understanding / moral knowing) occurs faster than the moral action. Students are easier to understand knowledge about environmental cares than to implement environmental awareness indicators in the form of concrete actions. Even the result of students 'environmental caring show different categories between observations and questionnaires, both of them show that the contextual science module is effective for improving students' environmental caring character. This result is reinforced by hypothesis testing that obtained the result that the value of $t=16,089$ bigger than $t$ table, which shows the average score of environmental cares are in the developing and entrust category. This is because the practicum module was presented in a contextual manner and gives students the opportunity to practice the character of environmental care in a real way in accordance with the condition of the students' daily life (contextual). In addition, the components of the contextual practicum module also increment the indicator of environmental caring character, ie; (1) 'modeling' component, facilitating wise characters using natural resourches, (2) 'inquiry' components, facilitating the character of environmental responsibility, (3) the 'learning community' component, facilitating the character of health ,hygiene appreciation, and character of hard work to protecting nature, (4) the 'reflection' component, facilitating the character of environmental responsibility. The results of this study are in line with the research conducted by Yustina \& Febrita[16], states that environment-based learning (contextual) has a positive impact on students 'attitudes and participation, involving students in learning with the environment can increase students awareness of the environment.

\section{Conclusion}

Based on the findings obtained in the research and discussion that has been done, it can be concluded several things as follows. (1) The validity of practicum module which developed is 3.40. (2) The practicality of practicum modules which developed is 3.50. (3) the effectiveness of the practicum module viewed from the skills of the science process is 85,86 belong to good category and the score of students environmental cares at moral knowing is 3,53 belong to entrust category and the score at moral behavior is 3,22 belong to developing category.

Referring to the research findings that have been done, then the suggestions that can be submitted as follows. First, teachers should be associate students with the real world problem in the practicum process. Second, teachers should prepare the completeness of the tools for support the practicum activities. Third, the schools and all components must be commitment to develop the expected character in the learning process. 


\section{Acknowledgement}

The authors would like to thank Prof. Dr. I Wayan Suastra, M.Pd for technical assistance and Dr. Ni Made Pujani, M.Si as supervisor. We also thank to all the parties involved in this research.

\section{Reference}

1. OECD, PISA 2015 Result and Focus (2015).

2. I.W.Suastra, I.B.P. Mardana, I.N.P. Suwindra, Research Grant (2006).

3. I.W.Suastra, Penelitian dan Pengembangan Pendidikan, 5, 258 (2011).

4. M. Crawford, Contextual Teaching and Learning:Strategies for Creating Contructivist Classrooms, NTPN, 11, 2 (2001).

5. C.C.Hudson, V.R. Whilsler, Contextual Teaching and Learning for Practitioners, SCI, 6, 55 (2012).

6. K.L. Ting, M.NY.Siew, Education and Learning, 3, 99 (2014).

7. I. W. Suastra, Pembelajaran Sains Terkini:Mendekatkan Siswa dengan Lingkungan Alamiah dan Sosial Budayanya, 5 (2013).

8. P.C.Buntod, P.Suksringan, A. Singsreevo, Effects of Learning environmental Education on Science Process Skills and Critical Thinking of Mathayomsuksa 3 Student with Different Learning Achievement, JSS, 6, 61(2010).

9. Kemdiknas, Panduan Pelaksanaan Pendidikan Karakter, 2001.

10. T. Lichona, Educating For Character, 105 (1943).

11. K.Komalasari, The Living Values-Based Contextual Learning to Develop the Student'Character, JSS, 8. 246-251 (2012).

12. R.J. Rezba, C.S. Sparaque, R.L. Fiel, H.J. Funk, J.R Okey, H.H. Jaus. Learning and Assessing Science Process Skills, Hunt Publishing Company (1995).

13. W.R. Borg, M.D. Gall, Educational Research: An Introduction. Fourth Edition (1983).

14. S.Thiagarajan, D.S. Semmel, M.I. Semmel, M.I., Instructional Development for Training Teachers of Exceptional Children: A Sourcebook (1974).

15. M. Crawford, Contextual Teaching and Learning: Strategies for Creating Constructivist Classrooms (Conclusion), JEL, 11, 4 (2013).

16. Yustina, E.Febrita, Increase Motivation and Knowledge the Environment through Contextual Model, ASS, 9, 241 (2013). 